SECTION 32. Jurisprudence.

\author{
Andrey Petrovich Mazurenko \\ Doctor of Law, Associate Professor, \\ North-Caucasian Federal University, Russia, Pyatigorsk \\ decanpetrovich@mail.ru
}

\title{
LAWMAKING POLICY: THEORETICAL AND APPLIED PROBLEMS
}

\begin{abstract}
This article analyzes the theoretical and applied problems of the poorly understood phenomenon of social reality as a law-making policy. The various perspectives on the role and place of law-making, policy-optimization lawmaking. Proposed an original approach to building evidence-based policy making activity.

Key words: law-making, law-making policy, theory, application problems, scientific validity, consistency.
\end{abstract}

\section{ПРАВОТВОРЧЕСКАЯ ПОЛИТИКА: ТЕОРЕТИЧЕСКИЕ И ПРИКЛАДНЫЕ ПРОБЛЕМЫ}

Аннотация: Статья посвящена анализу теоретических и прикладных проблем такого малоизученного явления сочиальной действительности как правотворческая политика. Приводятся различные точки зрения на роль и место правотворческой политики в деле оптимизачии правотворчества. Предлагаются оригинальные подходь $\kappa$ выстраиванию научно обоснованной политики в сфере правотворческой деятельности.

Ключевые слова: правотворчество, правотворческая политика, теория, прикладные проблемь, научная обоснованность, системность.

Одной из характерных черт развития общества в последние десятилетия стали масштабные преобразования во всех его сферах, вызвавшие появление новых тенденций, политико-правовых явлений и процессов, вследствие чего юридическая наука проявила заметный интерес к их исследованию. В частности, в эти годы, началась интенсивная разработка проблем правовой политики как нового и сложного по своей природе и структуре политико-правового феномена.

Обратим внимание, что именно в данный период пришло осознание того, что правовая политика, при всем многообразии характеристик и определений, понимается и воспринимается в обществе, прежде всего, как политика правотворческая. Несмотря на то, что ее базовую основу составляет политика правовая, исследуемое явление имеет свою самостоятельность и даже суверенность. Определяющим аргументом такого статуса правотворческой политики служит то, что, во-первых, она формируется и реализуется в наиболее важной юридической сфере - правовой, устанавливая при этом ее нормативно-концептуальные основы. Во-вторых, такая политика оказывает мощное воздействие на неюридические сферы общества (экономическую, социальную и др.), где с помощью присущих ей средств и методов, способствует решению важнейших государственных задач.

Сказанное подтверждает, что правотворческая политика является одним из новых, перспективных направлений исследований общетеоретических вопросов правоведения. На наш взгляд, базовой (сущностной) основой формирования правотворческой политики является политика правовая. Похожей точки зрения придерживается и С.В. Поленина: «Такое положение не случайно, поскольку, будучи закрепленной в преамбулах, определениях и статьях законов и иных 
нормативных правовых актов, правовая политика приобретает наиболее ясную и доступную для широкого обозрения и ознакомления населением форму» [4, с. 181].

У данной точки зрения, касающейся места и роли правотворческой политики в правовой действительности, есть оппоненты. Так, О.Ю. Рыбаков считает, что абсолютизировать, выделять ее в качестве самой главной формы реализации правовой политики вряд ли обоснованно. По его мнению, любые, самые правильные, справедливые, выверенные решения в области правотворчества останутся нереализованными в полной мере, если не будут подкреплены сильной политикой в области правоприменения [7, с. 9].

Думается, что с этим мнением трудно согласиться, поскольку правоприменительная практика в данном случае есть результат правотворческой политики, разработка концепции которой имеет важное теоретическое и практическое значение. Правотворческая политика призвана создавать условия для эффективной правотворческой (в т.ч. законотворческой) деятельности, участвовать в определении ее стратегических целей и решении тактических задач.

Характеризуя специфику правотворческой политики, обратим внимание на то, что она отличается сложностью и многообразием структуры. Среди видов правотворческой политики можно выделить законотворческую и подзаконную (нормотворческую) политику, текущую и перспективную, позитивную и негативную правотворческую политику. Речь также может идти об отраслевой правотворческой политике и о правотворческой политике применительно к различным сферам деятельности либо в отношении тех или иных категорий граждан. Важным основанием классификации правотворческой политики является видовое деление в соответствии с уровнями еe организации, где можно выделить международную, федеральную, региональную, муниципальную и локальную правотворческую политику. В зависимости от субъектного состава она может быть подразделена на правотворческую политику органов государства, санкционированную (делегированную) и правотворческую политику, осуществляемую с непосредственным участием населения.

Как видим, система субъектов правотворческой политики включает большой круг участников. Однако их перечень можно считать открытым, поскольку в новых российских условиях, влиять на формирование данной политики, участвовать в ее реализации могут и иные субъекты, помимо перечисленных выше.

Исходные принципы правотворческой политики, общие перспективы, основные направления и стратегия развития законодательства в концептуальном виде закреплены в Конституции РФ. Вместе с тем, помимо конституционных, правотворческая политика, на наш взгляд, должна базироваться на таких специфических принципах, как научная обоснованность, системность, предсказуемость и планомерность. Казалось бы, эти принципы совпадают с основными принципами правотворчества. Однако по отношению к правотворческой политике, они имеют свою направленность, поскольку предвосхищают и опосредуют деятельность по непосредственному формированию новых норм права. Специфика этих принципов для правотворческой политики заключается также в том, что здесь они применяются комплексно, в объективном единстве, без чего невозможно обеспечить эффективность их воздействия. Для нее они особо значимы именно потому, что взаимосвязаны и взаимообусловлены. Только применяемые вместе, данные принципы дают эффект, обеспечивают принятие целесообразных, легитимных, научно обоснованных законов и иных правовых актов. Отступление от них ведет к произвольным и ошибочным решениям, излишним затратам труда, времени, энергии правотворцев, снижению эффективности правового регулирования [6, с. 6,42$]$.

Из сказанного вытекает, что четкая, целостная и последовательная правотворческая политика есть необходимая предпосылка эффективности 
законодательной и иной правотворческой деятельности, основной целью которой должно быть решение социальных, экономических, политических и иных задач на различных уровнях правового регулирования. Для того, чтобы указанная цель могла претворяться в жизнь, нужно, чтобы не только правотворческая деятельность, но и положенная в ее основу правотворческая политика формировались путем выявления существенных потребностей в правовой регламентации определенных областей общественных отношений в интересах населения всей страны, входящих в Федерацию субъектов и муниципальных образований, а также при условии органичного, непротиворечивого вхождения данного закона или иного правового акта в систему законодательства [4, с. 182].

Как верно отмечается в литературе, правотворчество включает в себя ряд ступеней, этапов, звеньев и протекает под воздействием множества факторов социальной действительности, которые в своей совокупности и диалектическом сочетании определяют сущность той или иной правовой нормы, ее содержание и форму, ее положение в системе, отрасли и институте права, ее назначение и роль в жизни общества [2, с. 90]. Думается, что правотворческую политику, безусловно, следует считать одним из таких определяющих факторов.

Предпринятый краткий анализ показывает, что правотворческая политика явление сложное и неоднозначное. Основанная на правотворческой деятельности, она направлена на упорядочение этой деятельности и всестороннее совершенствование системы права. Залогом ее эффективности является то, что она использует в данном процессе инструменты правовой политики, составной частью, основным видом которой является. В то же время самостоятельность правотворческой политики подтверждается наличием отличительных признаков, позволяющих отграничить ее от других видов правовой политики. К числу таких признаков можно отнести следующие:

1) выступает как единый политико-правовой фактор правотворческой деятельности, основывается на ней и непосредственно воздействует на процессы создания и совершенствования системы права;

2) характеризуется многосубъектностью: в ее формировании и осуществлении принимают участие депутаты и работники аппаратов представительных органов власти, все без исключения субъекты права законодательной инициативы, представители научных организаций, различные институты гражданского общества, граждане РФ и т.д.;

3) отличается многоуровневостью: осуществляется на различных ступенях (уровнях) государственной и общественной организации (федеральном, региональном, муниципальном);

4) базируется на требовании обязательного использования научного потенциала в ходе законоподготовительных работ и процессе принятия правотворческих решений;

5) использует инструменты прогнозирования и планирования, основывающиеся на проведении социологических исследований, мониторинге действующего законодательства и правоприменительной практики, сравнительно-правовых исследованиях, правовом моделировании и др. научно обоснованных методах;

6) носит системный характер, заключающийся в стремлении к созданию взаимосогласованного, беспробельного и целостного законодательства;

7) является одновременно стратегией и тактикой в сфере правотворчества.

Таким образом, под правотворческой политикой следует понимать особое явление политико-правовой действительности, выражающееся в научно обоснованной, планомерной и системной деятельности государственных органов и негосударственных структур, направленной на определение стратегии и тактики правотворчества, осуществляемой на различных уровнях правового регулирования в целях обеспечения необходимых условий для создания непротиворечивой и целостной системы права. 
Предложенное определение отражает идеальную модель рассматриваемого феномена и потому не позволяет забывать о многочисленных проблемах правотворческой политики, которые возникают в процессе ее формирования и реализации, что, в свою очередь, требует соответствующих усилий со стороны научного сообщества по их дальнейшей теоретической разработке.

На сегодняшний день, правотворческая политика, к сожалению, относится к числу наименее разработанных правовых наук. Фактически речь идет о принципиально новой системе юридических знаний, имеющей специфичные предмет, метод и функциональное назначение. Однако, несмотря на слабую разработку, необходимость специального научного обоснования правотворческой политики и факт существования особой юридической науки «правотворческая политика» практически никем не оспаривается.

Правотворческая политика - особая наука, находящаяся на стыке теории государства и права и политологии. Она тесно связана как с отраслевой юридической наукой, так и с общетеоретической, но, тем не менее, сохраняет свою самостоятельность. Целью этой науки является применение на практике в ходе правотворческой деятельности достижений теории государства и права, воплощение в жизнь основных ее идей и принципов, подведение идеологической и научной основы под правотворческий процесс.

Правотворческая политика как наука представляет собой отрасль знаний о методологии и принципах эффективной правотворческой деятельности. Предмет правотворческой политики можно в общем виде определить как научную основу, то есть систему принципов, форм и методов, используемых в ходе планирования и принятия нормативных правовых актов, в целях формирования единой национальной системы права, модернизации и совершенствования ее элементов.

Наука правотворческой политики изучает особую сферу человеческой жизнедеятельности, связанной доктринальным обоснованием внешнего выражения и формального закрепления в системе нормативных правовых актов объективно существующих норм права. Главным объектом правотворческой политики как науки, главным источником знаний, основной практической базой (как для проведения исследований, так и для проверки полученных результатов) является правотворческая деятельность.

Правотворческая политика как наука включает в себя следующие основные институты:

- основные принципы правовой политики в сфере правотворчества;

- основные методы познания необходимости и определения способа правового регулирования;

- основные факторы, влияющие на формирование национальной системы права;

- основные приемы и способы модернизации и систематизации нормативноправового материала;

- основные правила анализа результатов правотворчества.

Возникновение правотворческой политики как науки вызвано практической необходимостью научного обоснования правотворческой деятельности. Эта необходимость обуславливает роль и место этой правовой науки в системе других юридических наук и ее функциональное назначение [8, с. 9-10].

Обращаясь же к анализу прикладных проблем правотворческой политики России, следует отметить, что объективная политико-правовая реальность свидетельствует об усилении влияния процессов глобализации на развитие системы права большинства современных государств. Но при этом нельзя допустить ситуации, когда приоритеты национальной правотворческой политики будут диктоваться извне. Россия - страна с богатейшей политической и правовой культурой, наиболее яркие 
достижения которой оказались возможными благодаря ориентации именно на традиционные гуманистические идеалы. Ее дальнейшее политико-правовое развитие должно строиться на гармоничном сочетании подобных идеалов и позитивных достижений мировой юридической практики.

Прикладные проблемы повышения эффективности правотворческой политики в юридической науке исследуются не так давно. В качестве важнейшей из них, на наш взгляд, является проблема ответственности за принимаемые законы и их реализацию. Более того, разработка вопросов ответственности за результаты правотворчества является одной из первоочередных задач по оптимизации правотворческой политики. Для урегулирования имеющихся противоречий на федеральном, региональном и муниципальном уровнях необходимо сформулировать и закрепить принципы и формы ответственности, подлежащей применению в случае принятия нормативных правовых актов, содержащих различного рода правотворческие ошибки. Это могла бы быть конституционно-правовая, административная или даже уголовная ответственность.

Среди других серьезных прикладных проблем модернизации правотворчества с помощью средств правотворческой политики следует назвать проблему разработки эффективно функционирующего механизма взаимодействия гражданского общества с органами государственной власти, подразумевающего подготовку решений по важнейшим социальным, экономическим и иным вопросам с учетом общественного мнения. Одним из направлений развития гражданского общества, позволяющим вовлечь его представителей в процесс принятия правотворческих решений, является законодательное оформление отношений с органами власти, обеспечивающее поддержание с ними постоянных контактов. В качестве примера подобного взаимодействия можно привести опыт работы Общественной палаты Российской Федерации, дискуссионных площадок крупнейших политических партий, практику общественного обсуждения законопроектов и т.п. Для развития правотворческой политики работа подобных институтов гражданского общества имеет большое практическое значение, в связи с чем нужно обращать большее внимание на возможности их влияния на осуществление данной политики с использованием, в частности, такого нового для России института, как «оценка регулирующего воздействия».

Она по некоторым основаниям схожа с социальной и общественной экспертизами и представляет собой инструмент, который используется для оценки вероятных результатов введения предлагаемых новых регулятивных актов или внесения изменений в существующие. В ряде стран, таких, как США, Австралия, Новая Зеландия, Канада, Мексика, процесс ОРВ успешно и в полной мере включен в государственную систему. Подобную систему можно использовать и в законотворческой деятельности России, чтобы сделать процесс принятия законов конкурентным, используя альтернативные проекты, по системе оценки «худший» - «лучший» [1, с. 198; 3, с. 41; 5, с. 85-102]. На наш взгляд, существует необходимость принятия федерального закона с соответствующим предметом регулирования, реализация которого позволила бы населению и другим субъектам гражданского общества своевременно получать развернутую и правдивую информацию о действиях законодателей на всех этапах правотворческого процесса и о планах развития отечественной системы права.

Можно выделить и такой аспект влияния мирового опыта на формирование национальной правотворческой политики, как изменение форм взаимодействия ее субъектов. Прежде всего, это касается возросшей активности Правительства и Президента в законопроектной деятельности. В то же время подобное перераспределение нагрузки в системе субъектов права законодательной инициативы никак не сказалось на качестве законов, поскольку большая их часть не имеет самостоятельного предмета и лишь вносит изменения и дополнения в ранее принятые акты. 
Подобное положение вещей выводит на еще одну ключевую проблему прикладного характера, имеющую существенное значение для выстраивания эффективной правотворческой политики. Речь идет о профессионализме лиц, участвующих в законопроектной работе, о качестве подготовки юридических кадров. Сегодня совершенно очевидна потребность в расширении и углублении профессиональной компетенции представителей исполнительных органов власти, парламентариев, работников аппаратов Администрации Президента, Правительства и палат Федерального Собрания в постижении специально-юридических знаний в области правотворчества и юридической (законодательной) техники. Вопрос об организации специальной образовательно-кадровой деятельности по созданию учебных программ, направленных на подготовку людей, способных решать задачи формирования и реализации целостной и непротиворечивой системы права, становится все более актуальным. В сфере высшего профессионального образования назрела необходимость развернуть государственную программу по подготовке таких специалистов.

В результате перечисленных и иных мер будут созданы необходимые условия для реального осуществления социальных функций отечественного правотворчества, модернизации его содержания, что, в свою очередь, усилит степень качественности, системности и последовательности в деятельности правотворческих органов, добавит концептуальное начало в развитие российской правотворческой политики.

\section{References:}

1. Доклад Совета Федерации Федерального Собрания РФ 2007 года «О состоянии законодательства в Российской Федерации» [Официальный сайт Совета Федерации Федерального Собрания Российской Федерации]. URL: http://www.council.gov.ru/journalsf/cat9/journal57/2008/number371.html обращения 25.03.2014).

2. Керимов Д.А. Философские проблемы права. М., 1972. -472с.

3. Малько А.В., Мазуренко А.П. Правотворческая политика России: история и современность: монография. М., 2013. -256с.

4. Поленина С.В. Правотворческая политика // Российская правовая политика: курс лекций / Под ред. Н.И. Матузова и А.В. Малько. М., 2003.

5. Правовой мониторинг. Научно-практическое пособие. М., 2009. -416с.

6. Российская правотворческая политика: учебное пособие / под ред. А.В. Малько, А.П. Мазуренко. Пятигорск, 2012.

7. Рыбаков О.Ю. Формы реализации правовой политики // Правовая политика и правовая жизнь. 2003. № 2 .

8. Чухвичев Д.В. Законодательная техника. М., 2008. 